\title{
Taxonomy of responsibility allocation in Human-Machine Systems with different levels of automation
}

\author{
Marcin Butlewski ${ }^{1, *}$ \\ ${ }^{1}$ Poznan University of Technology, Department of Ergonomics and Quality Engineering, Poland
}

\begin{abstract}
The paper analyses the available taxonomies of responsibility allocation in Human-Machine Systems. The basic assumptions for the division of responsibility in the system and the measures of system wellness are described, as well as the appropriateness of the assignment of responsibility in the system. Finally, a taxonomy of responsibility allocation, consisting of a combination of types of decision resources in the system, was proposed.
\end{abstract}

\section{Introduction}

In the anthropotechnical system, man and machine have extremely differing resource characteristics, which results in the different needs of each of these elements in relation to the requirements of the system. The human is particularly unreliable since, unlike the machine, he is not able to maintain for a long period of time and without interruption the high functional parameters required by the work, such as power, force, speed and sensitivity. Therefore, replacing human labor using machines (mechanization) and automated machines (automation) has become the main strategy in the design of HumanMachine (H-M) systems [1]. Reducing human labor can involve manual activities reducing physical effort and the associated risk of musculoskeletal disorders among different industry sectors $[2,3]$, however, currently it increasingly involves mental effort, the perception of information and the need for decision-making. The allocation of tasks (or responsibility for tasks due to the over simplification of the issue of the division of labor) between a human and a technical entity seems to be the key factor in determining the effectiveness and reliability of the H-M system. Increasingly complex H-M systems require a more sophisticated way of addressing the problem of responsibility allocation - therefore, this paper proposes taxonomy of responsibility allocation in Human-Machine systems.

\section{Criteria for the allocation of functions as a step towards responsibility allocation}

For years, the human seemed irreplaceable in areas of work that required the performance of non-standardized procedures, flexibility and unprogrammed action. In turn, the human

\footnotetext{
${ }^{*}$ Corresponding author: marcin.butlewski@put.poznan.pl
} 
"loses" with the machine due to his limited reaction time to signals and variable effectiveness with increasing fatigue. The human is also not capable of continuous work, especially when working in unfavorable environmental conditions, e.g. in a significant level of noise, an unfavorable microclimate. The human cannot generate forces rivaling those of machines and fails in situations of repeated and monotonous movements, however, in the end the human ensures the relatively high level of reliability of the system, as its overseer [4, p. 234]. This statement is only seemingly a paradox, because human reliability will be determined by his environment and the working conditions in which he will be put to the test, and one of the factors determining human effectiveness is monotony of work, resulting from the division of tasks in the work system.

With regard to the allocation of functions in the H-M system, there are a number of principles that determine what tasks should or should not be performed by the human - for example, in terms of the allocation of motor functions, the human should only perform those that do not overload him and simultaneously produce the appropriate amount of activity and motor skill [5]. Other decision-making rules developed in this area indicate the need to consider:

- who will be better at performing the given task - the so-called prevailing abilities,

- the good of the whole system, that is, the allocation should be carried out in such a way

- that the measurable values achieved by the system reach an acceptable maximum,

- the harmonization of information in the human-environment system so that the human is not overloaded to the point of impairing the effective performance of work,

- operator satisfaction, and thus adapting the technical system to fit the individual needs of the human.

The obvious difference in the effectiveness of the human and machine during the performance of certain tasks has contributed to the development of lists of the allocation of functions in the H-M system. Task allocation strategies based on the MABA-MABA approach (from the acronym Men Are Better At - Machines Are Better At) were initiated by Fitts [6,7]. This approach, known as the Fitts list, defines the functional division between the operator and machine in the H-M system. In the face of criticism, it has evolved from a strategy of resource complementarity (man and machine mutually complement each other in performing tasks), to a leftover allocation strategy (where all functions that can be automated should be relegated to machines, and the remaining functions should be left to the operators), and finally to a dynamic task allocation (DTA) strategy [8], although even this approach does not seem to exhaust the possibilities of task delegation in H-M systems. Table 1 presents the attributes of tasks, and the suggested relations related to task allocation, however, it should be noted that the division is not exclusive, but rather cooperative [9].

Table 1. Decision table on the allocation of functions in the designed anthropotechnical system [10].

\begin{tabular}{|l|l|l|}
\hline \multicolumn{1}{|c|}{ Task attributes } & \multicolumn{1}{c|}{ Human (H) } & \multicolumn{1}{c|}{ Technical Device (TD) } \\
\hline $\begin{array}{l}\text { Flexibility - ease of } \\
\text { adaptation to variable } \\
\text { conditions }\end{array}$ & $\begin{array}{l}\text { Well suited to a wide range of } \\
\text { variable tasks. }\end{array}$ & Less flexible - specialized. \\
\hline $\begin{array}{l}\text { Adaptation to changing } \\
\text { requirements }\end{array}$ & $\begin{array}{l}\text { Good adaptation to unexpected } \\
\text { changes in requirements - however, } \\
\text { may only work for a limited time in } \\
\text { an overload situation. }\end{array}$ & $\begin{array}{l}\text { Work in situations for which the } \\
\text { TD is not designed is not possible. }\end{array}$ \\
\hline Teaching and training & $\begin{array}{l}\text { Easy assimilation of a limited amount } \\
\text { of knowledge - improving } \\
\text { performance (to a certain level) is the } \\
\text { natural domain of man. }\end{array}$ & $\begin{array}{l}\text { Unlimited knowledge - improving } \\
\text { performance only within the } \\
\text { capacity of the system - requires } \\
\text { its control. }\end{array}$ \\
\hline
\end{tabular}




\begin{tabular}{|c|c|c|}
\hline Task attributes & Human (H) & Technical Device (TD) \\
\hline $\begin{array}{l}\text { Unstructured tasks in } \\
\text { uncertain conditions }\end{array}$ & $\begin{array}{l}\text { In most cases, has a large ability to } \\
\text { perform such tasks. }\end{array}$ & $\begin{array}{l}\text { Not adapted to this type of activity } \\
\text { - or a significant effort is required } \\
\text { to achieve a TD's ability to } \\
\text { perform such tasks to a certain } \\
\text { extent. }\end{array}$ \\
\hline Predictability of outcome & $\begin{array}{l}\text { Human activity is not determined and } \\
\text { predictable. }\end{array}$ & $\begin{array}{l}\text { Actions with known effectiveness } \\
\text { - to a large extent predictable. }\end{array}$ \\
\hline $\begin{array}{l}\text { Ability to receive and } \\
\text { recognize information }\end{array}$ & $\begin{array}{l}\text { Limited number of senses with a high } \\
\text { sensitivity results in a limited number } \\
\text { of recognizable patterns. }\end{array}$ & $\begin{array}{l}\text { TD can be adapted to recognize } \\
\text { any } \\
\text { (predictable) stimuli. High } \\
\text { performance in this area is } \\
\text { expensive. }\end{array}$ \\
\hline Monitoring & $\begin{array}{l}\text { Very poorly adapted for long-term } \\
\text { and routine monitoring due to time- } \\
\text { limited vigilance. }\end{array}$ & $\begin{array}{l}\text { Can perform long-term monitoring } \\
\text { and recognition of differences. }\end{array}$ \\
\hline $\begin{array}{l}\text { Incomplete and noisy } \\
\text { information }\end{array}$ & $\begin{array}{l}\text { Can act with information shortages or } \\
\text { low quality information. }\end{array}$ & \multirow{2}{*}{$\begin{array}{l}\text { Initially the machine fared quite } \\
\text { poorly in such situations, however, } \\
\text { work on the development of } \\
\text { artificial intelligence led to the } \\
\text { creation of decision-making } \\
\text { algorithms operating under } \\
\text { conditions of uncertainty [11]. } \\
\end{array}$} \\
\hline $\begin{array}{l}\text { Strategic, tactical, } \\
\text { organizational planning } \\
\text { and decision-making }\end{array}$ & $\begin{array}{l}\text { Well-adjusted when realistic decision } \\
\text { models and appropriate conditions (e.g. } \\
\text { stress reduction) are ensured. }\end{array}$ & \\
\hline $\begin{array}{l}\text { Induction and } \\
\text { generalization }\end{array}$ & $\begin{array}{l}\text { Can make decisions based on } \\
\text { inductive reasoning and generalizing } \\
\text { in new situations. }\end{array}$ & $\begin{array}{l}\text { Machines have quite a small } \\
\text { capacity for generalization and } \\
\text { inductive reasoning. }\end{array}$ \\
\hline Memory & $\begin{array}{l}\text { A limited short-term memory, and } \\
\text { long-term memory is exposed to } \\
\text { losses and changes in recorded } \\
\text { events. }\end{array}$ & $\begin{array}{l}\text { Memory unrestricted beyond the } \\
\text { imposed design limits (what and } \\
\text { how long to remember) and } \\
\text { phenomena resulting from damage } \\
\text { to technical objects. }\end{array}$ \\
\hline $\begin{array}{l}\text { Continuity of } \\
\text { performance }\end{array}$ & $\begin{array}{l}\text { Performance is a function of stress, } \\
\text { mental and physical fatigue. }\end{array}$ & $\begin{array}{l}\text { Performance is expressed by } \\
\text { mathematical-statistical } \\
\text { relationships. }\end{array}$ \\
\hline $\begin{array}{l}\text { Repeated and } \\
\text { monotonous tasks }\end{array}$ & $\begin{array}{l}\text { Human is not suitable for these tasks, } \\
\text { although through training can achieve } \\
\text { a high level of performance } \\
\text { temporarily. }\end{array}$ & $\begin{array}{l}\text { The machine is well suited to this } \\
\text { type of task. }\end{array}$ \\
\hline Physical abilities & Biologically limited. & $\begin{array}{l}\text { Compatible with the design } \\
\text { requirements. }\end{array}$ \\
\hline Speed & Biologically limited. & $\begin{array}{l}\text { An established function obtained } \\
\text { through the technical system - } \\
\text { considerable speed is possible. }\end{array}$ \\
\hline Accuracy & $\begin{array}{l}\text { High motor skills, but accuracy is } \\
\text { dependent on time spent on the } \\
\text { action/training. }\end{array}$ & $\begin{array}{l}\text { Accuracy can be designed as } \\
\text { needed, but high accuracy is } \\
\text { associated with a considerable } \\
\text { cost. }\end{array}$ \\
\hline $\begin{array}{l}\text { Resistance to } \\
\text { environmental factors }\end{array}$ & $\begin{array}{l}\text { Highly resistant in certain areas, } \\
\text { beyond which a considerable effort is } \\
\text { required to enable a person to work. }\end{array}$ & $\begin{array}{l}\text { Can work under almost all } \\
\text { conditions for which the machine } \\
\text { was designed. }\end{array}$ \\
\hline
\end{tabular}

Determining the allocation of functions in the event that the human and the technical equipment are equal in terms of their available features requires additional analysis and criteria. Helpful in this respect may be determining positions based on Price's diagram of allocation decisions between man and machine [12].

\section{Existing typologies in the field of responsibility allocation}

Due to the need to create a typology of task allocation in H-M systems that would allow the valuation of the division of functions, incremental scales, such as the 10-point Sheridan- 
Verplanck scale, are introduced. It determines the extent that human labor is assisted by automated machinery, ranging from level 1 , which means a total lack of assistance, up to level 10, meaning full automation of decision-making and execution of tasks [13]:

1. The system offers no assistance - the human must make all decisions and actions.

2. The system offers a complete set of decision/action alternatives, or

3. Narrows the selection down to a few options (based on the set limitations), or

4. Suggests one alternative, and

5. The system executes that suggestion if the human approves, or

6. The system allows the human a restricted time to veto before automatic execution, or

7. The system makes decisions and executes tasks automatically, then necessarily informs humans, and

8. Informs the human only if asked, or

9. Informs the human only if it, the computer, decides to.

10. The system decides everything and acts autonomously, ignoring the human.

The presented division, though cited in numerous publications, does not allow to determine the level of assistance the technical system offers the human in all areas of resource-efficient decision-making, in terms of perception, decision-making and task execution.

\section{Proposed typology of responsibility allocation}

The typology of responsibility allocation can be presented by a ternary division of action attributes - Fig. 1.
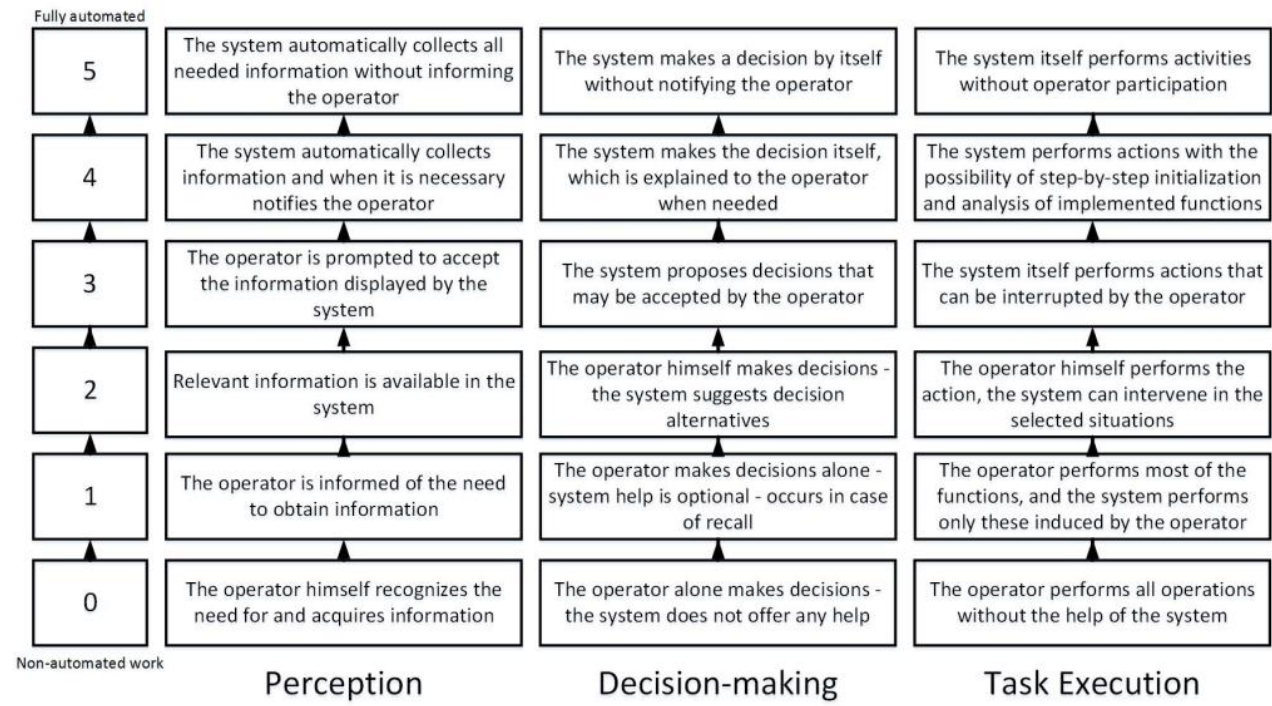

Fig. 1. Levels of automation for main decision resource categories [14].

The extent of the assistance offered to the operator within the H-M system is characterized by three dimensions of his activity (perception $X_{P}$, decision-making $X_{D}$ and task execution $\mathrm{X}_{\mathrm{TE}}$ ) and allows the definition of requirements for different tasks, which may be justified by safety requirements in a specific situation. 
For example, in the case of the risk of insufficient implementation resources, the $\left(X_{P} \cdot X_{D} \cdot X_{T E}>3\right)$ strategy can be selected. The functional description of the allocation of tasks may take the form presented in Figure 2.

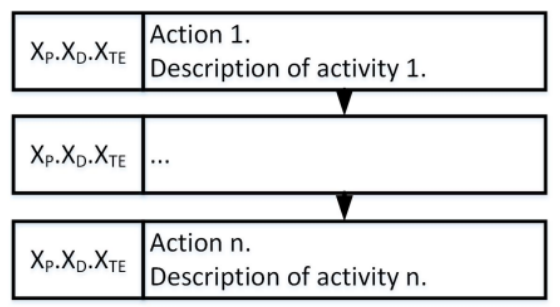

Fig. 2. Proposed structure for describing the levels of automation.

Certain code combinations for major resource categories do not seem to be possible, however, they cannot be excluded under specific conditions of a system's structure (e.g. air traffic control systems, etc.). If the operator makes decisions himself - the system suggests decision-making alternatives $\left(\mathrm{X}_{\mathrm{P}}, \mathrm{X}_{\mathrm{D}}(2), \mathrm{X}_{\mathrm{TE}}\right)$. These alternatives can be displayed with the percentage probability of a given decision-making alternative, which is characteristic for expert systems.

Mathematical calculations of the expected value for a particular combination of task allocations are also proposed, however, each combination requires the sequential ordering of the values of human and machine abilities to perform a given task and assigning them weights resulting from this order [14]. In determining the desired allocation of functions in the H-M system the Analytic Hierarchy Process (AHP) method is used quite often, and allows for a comparison of importance of a pair of criteria [15]. This approach requires the determination of evaluation criteria, among which the typical ergonomic criteria are found [16-18]:

- criteria related to the operator's well-being,

- criteria related to the operator's effectiveness,

- criteria related to the effectiveness of the system as a whole.

Each of the criteria groups consists of sub-criteria, whose great number cannot be presented in this publication. Some of the criteria will be interdependent and interpenetrating between the mentioned groups. The large number of criteria significantly lengthens the process of comparing them and thus method of support will be needed [19].

\section{Conclusion}

The allocation of tasks in the system must be dependent on the ability to maintain the performance of tasks over time. This implies the need to designate situations in which the human or machine will assume responsibility for the task being performed (Trading of Authority). This also demonstrates the need for a dynamic functional division. The allocation of responsibilities and the need for its exchange in the H-M system also arises due to situational or compensating resource deficits, among which time and information are the ones most commonly mentioned [20].

These resources are perceived as one because the time available is a factor influencing the ability to acquire and process information, so time will compensate for insufficient information within the system. Systems based on the principle of dynamic sharing of responsibility and the possibility of its exchange are a key element of flexible automation (also known as adaptive automation) [21], whose practical application is observed in intelligent driving systems. 


\section{References}

1. A.M. Lasota, K. Hankiewicz, In: P. M. Arezes, et al. (Eds.), Occupational Safety and Hygiene, SHO, 138 (2016)

2. A.M. Lasota, K. Hankiewicz, Proceedings of the International Conference on Economics and Management Innovations, 57, 272 (2016)

3. A. Misztal, M. Butlewski, A. Jasiak, S. Janik, Metalurgija, 54 (2), 429 (2015)

4. A.M. Lasota, K. Hankiewicz, Assessment of risk to work-related musculoskeletal disorders of upper limbs at welding stations, In: P. M. Arezes, et al. (Eds.), Occupational Safety and Hygiene, SHO, 138 (2016)

5. A.M. Lasota, K. Hankiewicz, Proceedings of the 2016 International Conference on Economics and Management Innovations, 57, 272 (2016)

6. Z. Ratajczak, Niezawodność człowieka w pracy: studium psychologiczne, (Human reliability at work: psychological study) Państwowe Wydawnictwo Naukowe (1988)

7. $* * *$ http://www.nop.ciop.pl - accessed 20.02.2017

8. A. Fasth, \& J. Stahre Proceedings of the 3rd CIRP Conference on Assembly Technologies and Systems 1, (2010)

9. P. M. Fitts, Human engineering for an effective air-navigation and traffic-control system, http://www.dtic.mil/get-tr-doc/pdf?AD=ADB815893 (1951)

10. J. Frohm, A. Karsvall, \& M. Hassnert, Proceedings of the 8th International Federation of Automatic Control Symposium. Gothenburg, Sweden, 161 (2003)

11. J. M. Hoc, \& C. Chauvin, Cooperative implications of the allocation of functions to humans and machines, http://jeanmichelhoc.free.fr/pdf/HocChau\%202011.pdf (2011)

12. ISO 9355-1:1999 Ergonomic requirements for the design of displays and control actuators - Part 1: Human interactions with displays and control actuators (reviewed in 2015)

13. C. J. Hopfe, Uncertainty and sensitivity analysis in building performance simulation for decision support and design optimization PhD diss., Eindhoven University, (2009)

14. H. E. Price, Human factors, 27 (1), 33 (1985)

15. R. Parasuraman, T. B. Sheridan, C. D. Wickens, IEEE Transactions on systems, man, and cybernetics-Part A: Systems and Humans, 30 (3), 286 (2000)

16. L. Yong ,W. Jiarui Dong, P. Zhenying, Regional Logistics ijssst.info/Vol-17/No1/paper12.pdf - accessed 25.02.2017 (2012)

17. Z. G. Wei, A. R. Paauw, P. A. Wieringa, Subjective evaluation of task allocation: An application of the analytic hierarchy process. Delft University of Technology, (1996)

18. A. Górny, Posters Extended Abstracts : International Conference, HCI International 2014, Communications in Computer and Information Science, 435, 449 (2014)

19. A. Górny, MATEC Web of Conferences (the 4th International Conference on Computing and Solutions in Manufacturing Engineering 2016, 94, (2017)

20. S. Kłos, J. Patalas-Maliszewska, Throughput Analysis of Automatic Production Lines Based on Simulation Methods. Intelligent Data Engineering and automated learning IDEAL 2015. In.: Jackowski, K., Burduk, R., Walkowiak, K., Wozniak, M., Yin, H. (eds.) Lecture Notes in Computer Science, 9375, 181 (2015)

21. R. Sika, M. Rogalewicz, Management and Production Engineering Review, 7 (4), 97 (2016)

22. T. Inagaki \& Y. Nagai, Journal of Mechanical systems for Transportation and Logistics, 1 (2), 213 (2008)

23. T. Inagaki, Cognition, Technology \& Work, 8 (3), 161 (2006) 